\title{
Adaptability and stability of flood-irrigated rice cultivars released to the subtropical region of Brazil
}

\author{
Eduardo Anibele Streck ${ }^{(1)}$, Ariano Martins de Magalhães Júnior(2), Paulo Ricardo Reis Fagundes(2), \\ Gabriel Almeida Aguiar ${ }^{(1)}$, Paulo Henrique Karling Facchinello(1) and Antônio Costa de Oliveira ${ }^{(1)}$
}

\begin{abstract}
(1)Universidade Federal de Pelotas, Avenida Eliseu Maciel, s/no, Caixa Postal 354, CEP 96010-610 Capão do Leão, RS, Brazil. E-mail: streck.eduardo@gmail.com, gabrielalmeidaaguiar@yahoo.com.br, phfacchinello@gmail.com, acostol@cgfufpel.org (2)Embrapa Clima Temperado, Rodovia BR-392, Km 78, 9o Distrito, Monte Bonito, Caixa Postal 321, CEP 96010-971 Pelotas, RS, Brazil. E-mail: ariano.martins@embrapa.br, paulo.fagundes@embrapa.br
\end{abstract}

\begin{abstract}
The objective of this work was to estimate the effects of genotype $\mathrm{x}$ environment interaction and the genetic potential of flood-irrigated rice cultivars, released between 1972 and 2017, for the state of Rio Grande do Sul, Brazil. The experiments were carried out in the field, in all agroclimatic regions of floodirrigated rice crop in the state, between the 2005/2006 and 2015/2016 crop years, totaling 60 environments (trials), with 1,961 experimental units. Twenty-five cultivars of irrigated rice were evaluated for the traits grain yield, plant height, days to flowering, and whole grain quality after milling. The values of adaptability and stability were estimated with the aid of mixed models. The rice cultivars BRS Pampa, BRS Pampeira, and BRSCIRAD 302 showed simultaneously high-genotypic grain yield, adaptability, stability, good agronomic traits, and good whole-grain yield after milling. 'BRSCIRAD 302' and 'BRS Pampa' show high-yield stability and can be recommended for all rice cultivation regions of Rio Grande do Sul. 'BRS Pampeira' is responsive to environmental improvements and is indicated for high-technology conditions.
\end{abstract}

Index terms: Oryza sativa, genotype x environment interaction, mixed models, plant breeding, zoning of cultivars.

\section{Adaptabilidade e estabilidade de cultivares de arroz irrigado por inundação lançadas para a região subtropical do Brasil}

Resumo - O objetivo deste trabalho foi estimar os efeitos da interação genótipo $\mathrm{x}$ ambiente e o potencial genotípico de cultivares de arroz irrigado por inundação, lançadas entre 1972 e 2017, para o Rio Grande do Sul. Os experimentos foram realizados em campo, em todas as regiões agroclimáticas de cultivo de arroz irrigado por inundação do estado, entre os anos agrícolas de 2005/2006 e 2015/2016, no total de 60 ambientes, com 1.961 unidades experimentais. Vinte e cinco cultivares de arroz irrigado foram avaliadas quanto aos caracteres produtividade de grãos, altura de plantas, dias para o florescimento e qualidade de grãos inteiros após o beneficiamento. Os valores de adaptabilidade e estabilidade foram estimados por meio de modelos mistos. As cultivares de arroz BRS Pampa, BRS Pampeira e BRSCIRAD 302 apresentaram, simultaneamente, alta produtividade genotípica de grãos, adaptabilidade, estabilidade, bons atributos agronômicos e bom rendimento de grãos inteiros após o beneficiamento. 'BRSCIRAD 302' e 'BRS Pampa' apresentam alta estabilidade produtiva e podem ser recomendadas para cultivo em todas as regiões orizícolas do Rio Grande do Sul. 'BRS Pampeira' é responsiva às melhorias do ambiente e é indicada para condições de alta tecnologia.

Termos para indexação: Oryza sativa, interação genótipo x ambiente, modelos mistos, melhoramento genético, zoneamento de cultivares.

\section{Introduction}

Rice (Oryza sativa L.) is the dietary basis of half the world's population (Hao \& Lin, 2010). In Brazil, flood-irrigated rice has a high-economic and social importance, and it is mainly produced in lowland areas. Rice in these areas shows high yields; however, there is a range of other agroclimatic regions, as well as technology uses. This generates diverse phenotypic responses of the genotype in the different regions, due to genotype $\mathrm{x}$ environment $(\mathrm{GxE})$ interactions, which particularly affect the quantitative traits.

In order to obtain more precise estimates of GxE effects, it is necessary to conduct experiments in as many numbers of sites and years as possible, to evaluate the magnitude of the interactions and their possible
Pesq. agropec. bras., Brasília, v.53, n.10, p.1140-1149, Oct. 2018 DOI: 10.1590/S0100-204X2018001000007
This is an open-access article distributed under the Creative Commons Attribution 4.0 International License 
impact on the selection and recommendation of cultivars (Silva et al., 2013). Therefore, for the cultivar maximum yield performance, it is necessary to carry out comparative tests in different environments, to determine yield, adaptability, and stability to different agroclimatic conditions. The knowledge of these environmental requirements and peculiarities of the main available cultivars allows of the selection of the most appropriate genotypes to each crop and growing condition. Thus, for cultivar recommendation, it is essential to determine the adaptability (broad or specific) and stability in each production region.

GxE can be studied by measures of adaptability and stability, which allows of a simple interpretation of a large dataset. In the context of mixed models, the harmonic mean of the relative performance of genetic values (MHPRVG) (Resende, 2007) has been shown to be one of the efficient alternatives for the simultaneous evaluation of genotypes for yield, adaptability, and stability, mainly when unbalanced data are produced (Balestre et al., 2010; Borges et al., 2010). This mixed model approach has been used efficiently in the analyses of numerous crops, such as sugarcane (Bastos et al., 2007), carrot (Silva et al., 2011), common beans (Torres et al., 2015), corn (Mendes et al., 2012; Faria et al., 2017), and rice (Colombari Filho et al., 2013).

Currently, the development of new high-yielding cultivars for different growing conditions (intrinsic conditions of planting, management, and climate) is one of the great challenges of breeders to attend the development requirements of technologies compatible with flood-irrigated rice. In this way, the plant breeding programs has developed numerous cultivars to meet the demand of various segments of cereal production chains. However, there is a lack of scientific information regarding the response of these floodirrigated rice cultivars released in Rio Grande do Sul and their interactions with the growing environments.

The objective of this work was to estimate the effects of $\mathrm{GxE}$ and the genetic potential of flood-irrigated rice cultivars released between 1972 and 2017 for the state of Rio Grande do Sul, Brazil.

\section{Materials and Methods}

The experiment was carried out in all agroclimatic regions of flood-irrigated rice cultivation in the state of Rio Grande do Sul, which are: Fronteira Oeste,
Campanha, Depressão Central, Planície Costeira Interna e Planície Costeira Externa, and Zona Sul. Twenty-five flood-irrigated rice cultivars released by the Embrapa breeding program for Southern Brazil, from 1972 to 2017, were used (Table 1). These cultivars were released over 46 years to meet the needs of the main production chain and their genetic constitutions that define the morphological traits, and purposes of use have changed over time.

The evaluations were evaluated in 60 environments, covering 1,961 experimental units. The number of sites in each of the 11 years of trial ranges from two to seven, depending on the availability of annual partnerships with companies and rural producers.

The experiment was carried out in randomized complete block design, with four replicates, for which the plots were composed of nine $5 \mathrm{~m}$ rows, spaced at $0.20 \mathrm{~m}$ between lines. The useful plot area was composed by the central $4 \mathrm{~m}$ lines of the seven internal ones, in order to exclude any incident effect on the border. Sowing was performed in conventional system, with one mechanical sowing of plots. The cultivation followed technical recommendations for flood-irrigated rice crop in Southern Brazil. The permanent flood irrigation system was used until the final maturation stage of the genotypes.

The following agronomic traits were evaluated: grain yield ( $\left.\mathrm{kg} \mathrm{ha}^{-1}\right)$ adjusted to $13 \%$ humidity; plant height $(\mathrm{cm})$ in the maturation stage, by measuring the length of the main tiller from the soil surface to the tip of panicles; number of days to flowering, measured by the number of days from emergence up to $50 \%$ of the panicles exposed; and the percentage of whole grains after milling, obtained by peeling and polishing of grains in a mini test device.

At first, the trials were grouped, considering each environment composed by a site in a given cultivation year. Not all the cultivars were evaluated in all the sites and cultivation years, since new cultivars were released over the evaluation period. Thus, the estimates of variance components were obtained by the residual maximum likelihood (REML) method, and the prediction of genetic values of each individual was performed with the best unbiased linear prediction procedure (Blup). The predicted values of the random effects (EBlup), associated to each of the genotypes, included a share allocated to the estimation of constant $\mu \mathrm{p}$ means (common average of cultivars without 
random genotypic deviations), and another share referring to the particular genotypic effects of each genotype.

The analyses were performed with the statistical software Selegen-REML/Blup (Resende, 2016), by which the variance components were obtained according to the linear mixed model

$\mathrm{y}_{\mathrm{ijkn}}=\mu+\mathrm{g}_{\mathrm{i}}+\mathrm{b}_{\mathrm{j}(\mathrm{kn})}+\mathrm{l}_{\mathrm{k}}+\mathrm{a}_{\mathrm{n}}+\mathrm{gl}_{\mathrm{ik}}+\mathrm{ga}_{\mathrm{in}}+\mathrm{la}_{\mathrm{kn}}+\mathrm{gla}_{\mathrm{ikn}}+\varepsilon_{\mathrm{ijkn}}$

in which: $\mathrm{y}_{\mathrm{ijkn}}$ is the observed value of the $\mathrm{i}^{\text {th }}$ genotype, in the $\mathrm{j}^{\text {th }}$ block, in the $\mathrm{k}^{\text {th }}$ environment, in the $\mathrm{n}^{\text {th }}$ harvest season; $\mu$ is the effect of the general mean; $g_{i}$ is the random effect of genotype $i ; b_{j(k n)}$ is the fixed effect of block $\mathrm{j}$, inside site $\mathrm{k}$, and year $\mathrm{n} ; 1_{\mathrm{k}}$ is the random effect of site $\mathrm{k} ; \mathrm{a}_{\mathrm{n}}$ is the random effect of year $\mathrm{n} ; \mathrm{gl}_{\mathrm{ik}}$ is the random effect of the genotype $\mathrm{x}$ site interaction; $\mathrm{ga}_{\mathrm{in}}$ is the random effect of the genotype $\mathrm{x}$ year interaction; $\mathrm{la}_{\mathrm{kn}}$ is the random effect of the site $\mathrm{x}$ cultivation year interaction; gla $_{\mathrm{ikn}}$ is the random effect of the genotype $\mathrm{x}$ site $\mathrm{x}$ year interaction; and $\varepsilon_{\mathrm{ijkn}}$ is the error or experimental residue.

The statistical matrix used to estimate the harmonic mean of the relative performance of genetic values (MHPRVG) was obtained from the model $\mathrm{y}=\mathrm{Xr}+\mathrm{Zg}+\mathrm{Wi}+\varepsilon$, in which: $\mathrm{y}$ is the data vector; $\mathrm{r}$ is the block effect vector, considered as fixed, added to the general average; $g$ is the genotypic effect vector, considered as random; $i$ is the $\mathrm{GxE}$ (random) interaction effect vector; $\varepsilon$ is the error or residue (random) vector; and $\mathrm{X}, \mathrm{Z}$, and $\mathrm{W}$ represent the incident matrices for these effects.

The harmonic mean of genetic values $\left(\mathrm{MHVG}_{\mathrm{i}}\right)$ and the relative performance of the predicted genotypic values (PRVG) was obtained, respectively, by

Table 1. Flood-irrigated rice (Oryza sativa) cultivars used, with their respectively years of release, in the experimentation of 11 agricultural years, in different sites in the state of Rio Grande do Sul, Brazil.

\begin{tabular}{|c|c|c|c|c|c|c|c|c|c|c|c|c|}
\hline \multirow[t]{2}{*}{ Cultivar } & \multirow[t]{2}{*}{ Year } & \multicolumn{11}{|c|}{ Crop year } \\
\hline & & $\begin{array}{l}2005 / \\
2006 \\
\end{array}$ & $\begin{array}{l}2006 / \\
2007 \\
\end{array}$ & $\begin{array}{l}2007 / \\
2008 \\
\end{array}$ & $\begin{array}{l}2008 / \\
2009 \\
\end{array}$ & $\begin{array}{l}2009 / \\
2010 \\
\end{array}$ & $\begin{array}{l}2010 / \\
2011 \\
\end{array}$ & $\begin{array}{l}2011 / \\
2012 \\
\end{array}$ & $\begin{array}{l}2012 / \\
2013 \\
\end{array}$ & $\begin{array}{l}2013 / \\
2014 \\
\end{array}$ & $\begin{array}{l}2014 / \\
2015 \\
\end{array}$ & $\begin{array}{l}2015 / \\
2016 \\
\end{array}$ \\
\hline IAS 12-9 (Formosa) & 1972 & & & & & & & & & & & * \\
\hline BR/IRGA $409^{(1)}$ & 1979 & * & $*$ & * & $*$ & $*$ & * & $*$ & $*$ & $*$ & $*$ & $*$ \\
\hline BR/IRGA 410 & 1980 & $*$ & $*$ & $*$ & $*$ & $*$ & $*$ & $*$ & $*$ & & & * \\
\hline BR/IRGA 411 & 1985 & & & & & & & & & & & $*$ \\
\hline BR/IRGA 412 & 1986 & & & & & & & & & & & * \\
\hline BR/IRGA 413 & 1986 & & & & & & & & & & & * \\
\hline BR/IRGA 414 ${ }^{(1)}$ & 1987 & & & & & & & & & & & * \\
\hline BRS 6 Chuí & 1991 & $*$ & $*$ & $*$ & $*$ & $*$ & & & & & & * \\
\hline BRS 7 Taim & 1991 & $*$ & $*$ & * & $*$ & $*$ & $*$ & * & $*$ & $*$ & $*$ & * \\
\hline BRS Ligeirinho & 1995 & & & & & & & & & & & * \\
\hline BRS Agrisul & 1995 & & & & & & & & & & & * \\
\hline BRS Bojuru & 1997 & & & & & & & & & & & * \\
\hline BRS Atalanta & 1999 & $*$ & $*$ & $*$ & $*$ & & & & & & & * \\
\hline BRS Firmeza & 1999 & $*$ & $*$ & $*$ & $*$ & & & & & & & * \\
\hline BRS Pelota & 2000 & $*$ & $*$ & $*$ & $*$ & $*$ & & & & & & * \\
\hline SCSBRS 113 - Tio Taka ${ }^{(2)}$ & 2004 & & & & & & & & & & & * \\
\hline BRS Fronteira & 2005 & $*$ & $*$ & $*$ & $*$ & $*$ & $*$ & $*$ & & & & * \\
\hline BRS Querência & 2005 & $*$ & $*$ & * & $*$ & $*$ & $*$ & $*$ & $*$ & $*$ & * & * \\
\hline BRSCIRAD $302^{(3)}$ & 2010 & & & & & & $*$ & & & & & * \\
\hline BRS Sinuelo CL & 2010 & & & & & & $*$ & $*$ & $*$ & $*$ & $*$ & $*$ \\
\hline BRS Pampa & 2011 & & & & & & $*$ & $*$ & $*$ & $*$ & $*$ & * \\
\hline BRS 358 & 2015 & & & & & & & & & & & * \\
\hline BRS AG & 2015 & & & & & & & & & & & $*$ \\
\hline BRS Pampeira & 2016 & & & & & & & & & $*$ & $*$ & $*$ \\
\hline BRSCIRAD AH703 CL ${ }^{(3)}$ & 2017 & & & & & & & & $*$ & $*$ & * & * \\
\hline Number of genotypes & & 9 & 9 & 9 & 9 & 7 & 8 & 7 & 7 & 7 & 7 & 25 \\
\hline Number of sites & & 2 & 6 & 7 & 7 & 6 & 3 & 5 & 6 & 7 & 4 & 7 \\
\hline
\end{tabular}

${ }^{(1)}$ Cultivar released by Embrapa and IRGA (Instituto Rio Grandense do Arroz). ${ }^{(2)}$ Cultivar released by Embrapa and Epagri (Empresa de Pesquisa Agropecuária e Extensão Rural de Santa Catarina). ${ }^{(3)}$ Hybrid released by Embrapa and Cirad. 


$$
\begin{aligned}
& \operatorname{MHVG}_{\mathrm{i}}=\mathrm{n} /\left[\sum_{\mathrm{j}=1}^{\mathrm{n}}\left(1 / \mathrm{Vg}_{\mathrm{ij}}\right)\right] \text { and } \\
& \operatorname{PRVG}_{\mathrm{i}}=(1 / \mathrm{n}) \times\left[\sum_{\mathrm{j}=1}^{\mathrm{n}}\left(\mathrm{Vg}_{\mathrm{ij}} / \mu_{\mathrm{i}}\right)\right] ;
\end{aligned}
$$

and the model which was considered simultaneously for yield, adaptability, and stability, obtained by harmonic mean of the relative performance of the genetic values (MHPRVG), was calculated by

$$
\text { MHPRVG }_{i}=n / \sum_{j=1}^{n}(1 / P R V G),
$$

in which, $\mathrm{n}$ is the number of environments where the genotype $i$ was evaluated; $\operatorname{Vg}_{\mathrm{ij}}$ is the genotypic value of the genotype $i$ in the environment $j$, expressed as the proportion of the average of this environment; and $\mu_{j}$ is the general mean of each environment $\mathrm{j}$ (Resende, 2016).

\section{Results and Discussion}

Grain yield, number of days to flowering, and plant height showed a large share of the total phenotypic variation $\left(\hat{\sigma}_{\mathrm{f}}^{2}\right)$ of genetic origin $\left(\hat{\sigma}_{\mathrm{g}}^{2}\right)$, which can be evidenced by the high estimated values of total genotypic effect and heritability $\left(\hat{\mathrm{h}}_{\mathrm{g}}^{2}\right)$, even though these are considered traits of quantitative genetic inheritance (Table 2).

However, for the trait percentage of whole grains after milling, there was a high contribution of the GxE complex interaction (low-genotypic correlation between genotype $\mathrm{x}$ year $\mathrm{x}$ site) and low heritability. Grain quality traits are highly affected by the environment in the irrigated rice cropping (Cameron et al., 2008; Hakata et al., 2012; Lyman et al., 2013; Li et al., 2014; Xu et al., 2015).

In the comparative trials of cultivars, in order to have a good experimental reliability, the genetic and statistical approaches should show the proportion between the genetic and residual variations associated to the studied trait; therefore, the selective accuracy is the most indicated parameter (Resende \& Duarte, 2007). Accuracies of $0.97,0.98,0.99$, and 0.77 were observed for yield, cycle, height, and percentage of whole grains, respectively.

The high number of evaluated trials in different sites, during the 11 agricultural years, led to precise estimates of the genotypic value of the cultivars and of the GxE interaction effect. The presence of such interaction makes it difficult to recommend a single cultivar for all the producing environments; however, it allows of the recommendation of adapted cultivars to each environment. This accuracy can be verified by the estimates of the genetic and variance components (Table 2).

Based on the genotypic values and the measures of adaptability and stability obtained, the genetic potential for grain yield $\left(\mathrm{G}_{\mathrm{i}}\right)$ of 'BRS Pampa' $\left(9,837 \mathrm{~kg} \mathrm{ha}^{-1}\right)$, 'BRSCIRAD 302' (9,247 $\left.\mathrm{kg} \mathrm{ha}^{-1}\right)$, 'BRS Pampeira' $\left(9,216 \mathrm{~kg} \mathrm{ha}^{-1}\right)$, and 'BRSCIRAD AH703 CL' (9,093 $\mathrm{kg} \mathrm{ha}^{-1}$ ) could be highlighted. These genotypes showed genetic potentials above $9,000 \mathrm{~kg} \mathrm{ha}^{-1}$ (Table 3), and it should be noted that the predicted genetic values were validated by high accuracy.

Table 2. Estimates of variance components and genetic parameters for the traits grain yield (GY), days to flowering (DTF), plant height (PH), and percentage of whole grains after milling (WG) of 25 irrigate rice (Oryza sativa) cultivars, evaluated in 60 environments of the state of Rio Grande do Sul, Brazil ${ }^{(1)}$.

\begin{tabular}{lcccc}
\hline $\begin{array}{l}\text { Variance } \\
\text { component }^{(1)}\end{array}$ & $\begin{array}{c}\text { Grain yield } \\
\left(\mathrm{kg} \mathrm{ha}^{-1}\right)\end{array}$ & $\begin{array}{c}\text { DTF } \\
(\text { days })\end{array}$ & $\begin{array}{c}\text { Plant height } \\
(\mathrm{cm})\end{array}$ & $\begin{array}{c}\text { WG } \\
(\%)\end{array}$ \\
\hline$\hat{\sigma}_{\mathrm{g}}^{2}$ & $1,787,804.963$ & 75.644 & 39.733 & 4.704 \\
$\hat{\sigma}_{\text {ga }}^{2}$ & $12,678.722$ & 3.187 & 3.341 & 0.250 \\
$\hat{\sigma}_{\text {gl }}^{2}$ & $273,379.473$ & 0.622 & 0.620 & 0.111 \\
$\hat{\sigma}_{\text {gla }}^{2}$ & $771,868.191$ & 11.557 & 4.981 & 11.185 \\
$\hat{\sigma}_{\mathrm{e}}^{2}$ & $856,431.061$ & 9.082 & 17.437 & 7.801 \\
$\hat{\sigma}_{\mathrm{f}}^{2}$ & $3,702,162.410$ & 100.093 & 66.112 & 24.051 \\
$\hat{\mathrm{h}}_{\mathrm{g}}^{2}$ & $0.483 \pm 0.040$ & $0.756 \pm 0.060$ & $0.601 \pm 0.050$ & $0.196 \pm 0.030$ \\
$\hat{\mathrm{c}}_{\mathrm{ga}}^{2}$ & 0.003 & 0.032 & 0.051 & 0.010 \\
$\hat{\mathrm{c}}_{\mathrm{gl}}^{2}$ & 0.074 & 0.006 & 0.009 & 0.005 \\
$\hat{\mathrm{c}}_{\mathrm{gla}}^{2}$ & 0.208 & 0.115 & 0.075 & 0.465 \\
$\hat{\mathrm{A}}_{\mathrm{g}}^{\mathrm{c}}$ & 0.970 & 0.990 & 0.980 & 0.770 \\
$\hat{\mathrm{r}}_{\mathrm{gl}}$ & 0.867 & 0.992 & 0.985 & 0.977 \\
$\hat{\mathrm{r}}_{\mathrm{ga}}$ & 0.993 & 0.960 & 0.922 & 0.950 \\
$\hat{\mathrm{r}}_{\mathrm{gl}}$ & 0.868 & 0.992 & 0.986 & 0.978 \\
$\hat{\mathrm{r}}_{\mathrm{ga}}{ }^{1}$ & 0.994 & 0.960 & 0.924 & 0.951 \\
$\hat{\mathrm{r}}_{\mathrm{gla}}$ & 0.628 & 0.831 & 0.816 & 0.289 \\
$\hat{\mu}^{\mathrm{\mu}}$ & $7,718.2$ & 89.0 & 94.2 & 60.6 \\
\hline
\end{tabular}

(1) $\hat{\sigma}_{\mathrm{g}}^{2}, \hat{\sigma}_{\mathrm{ga}}^{2}, \hat{\sigma}_{\mathrm{gl}}^{2}, \hat{\sigma}_{\mathrm{gla}}^{2}, \hat{\sigma}_{\mathrm{e}}^{2}, \hat{\sigma}_{\mathrm{f}}^{2}$, are respectively the estimates of the genotypic variance, genotype $x$ year interaction, genotype $x$ site interaction, genotype $\mathrm{x}$ site $\mathrm{x}$ year interaction, residual variance and phenotypic individual; $\hat{\mathrm{h}}_{\mathrm{g}}^{2}$, estimate of the coefficient of heritability related to the individual plots of total genotypic effects; $\hat{c}_{\text {ga }}^{2}$ and $\hat{c}_{\mathrm{gl}}^{2}$, respectively, estimates of coefficient of determination of the genotype $\mathrm{x}$ year interaction effects, and genotype $x$ site interaction effects; $\hat{c}_{\text {gla }}^{2}$, estimate of the coefficient of heritability in the broad sense, at the level of averages of genotypes; $\hat{\mathrm{A}}_{\mathrm{g}}^{\mathrm{c}}$, estimate of the accuracy of selection, at the level of averages of genotypes. The estimates $\hat{\mathrm{r}}_{\mathrm{gl}}, \hat{\mathrm{r}}_{\mathrm{ga}}, \hat{\mathrm{r}}_{\mathrm{gl} \_\mathrm{a}}, \hat{\mathrm{r}}_{\mathrm{ga} \_}, \hat{\mathrm{r}}_{\mathrm{gla}}$ are genotypic correlations respectively of: genotype $\mathrm{x}$ site; genotype $\mathrm{x}$ year; genotype $\mathrm{x}$ site with the year; genotype $\mathrm{x}$ year with the site; and of genotype $\mathrm{x}$ year $\mathrm{x}$ site; $\hat{\mu}$, estimate of general mean of the experiment. 
As to the genotypic stability (MHVG), 'BR/IRGA 412', 'BRS Pampa', and 'BRS Agrisul' showed a stable behavior in the studied environments. The higher stability under conditions of environmental variations was obtained by 'BRSCIRAD 302' (Table 3), that is a hybrid released in 2010. This high-yield stability was expected because hybrids are less affected by adverse cultivation conditions. This was reported for 140 hybrid cultivars subjected to three levels of nitrogen $\left(0,60\right.$, and $\left.120 \mathrm{~kg} \mathrm{ha}^{-1}\right)$, in which positive heterosis for grain yield was observed, irrespectively of the tested environment (Young \& Virmani, 1990).

Regarding the genotypic adaptability (PRVG), the cultivars that showed the highest genetic potential for yield were also considered more adapted to the cultivated regions in Rio Grande do Sul (Table 3). 'BRS Pampa', 'BRS Pampeira', 'BRSCIRAD AH703 CL', and 'BRSCIRAD 302' were quite productive and responsive to the cultivated conditions in Rio Grande do Sul.
The MHPRVG method, which is obtained by penalizing the genotypic instability effect and capitalizing by the favorable response of the genotype to the environment, allowed to discriminate the floodirrigated rice cultivars considering, simultaneously, yield, genotypic adaptability, and stability (Table 3). Therefore, the outperformers were again 'BRS Pampa', 'BRS Pampeira', 'BRSCIRAD AH703 CL' and 'BRSCIRAD 302' that showed their greater potential for cultivation in lowland regions under flood-irrigated system. The high-yield potential of 'BRS Pampeira' had already been reported by Magalhães Júnior et al. (2017a).

The amplitude of fluctuation of genotypic responses, observed for each cultivar among environments, can be attributed to changes associated to cultivation years and sites within the year. The genetic parameters indicated three favorable and three unfavorable regions (Figure 1). The most favorable one was the Campanha region, with $10,389 \mathrm{~kg} \mathrm{ha}^{-1}$ average yield,

Table 3. Predicted genotypic value $\left(\hat{\mathrm{G}}_{\mathrm{i}}\right)$, selective accuracy $\left(\hat{\mathrm{r}}_{\mathrm{g} g}\right)$, genotypic stability (MHVG), genotypic adaptability (PRVG), and adaptability and stability of the genotypic values (MHPRVG), for the trait grain yield (kg ha-1) of 25 irrigated rice (Oryza sativa) cultivars, evaluated in 60 environments in the state of Rio Grande do Sul, Brazil ${ }^{(1)}$.

\begin{tabular}{|c|c|c|c|c|c|c|c|c|c|c|}
\hline Cultivar & $\mathrm{YL}^{(1)}$ & $\hat{\mathrm{r}}_{\hat{\mathrm{g} g}}$ & $\mathrm{R}^{\mathrm{o}(2)}$ & $\hat{\mathrm{G}}_{\mathrm{i}}$ & $\mathrm{R}^{\mathrm{o}}$ & MHVG & $\mathrm{R}^{\mathrm{o}}$ & PRVG & $\mathrm{R}^{\mathrm{o}}$ & MHPRVG \\
\hline BRS Pampa & 2011 & 0.97 & $1^{\text {st }}$ & 9837 & $3^{\text {rd }}$ & 9455 & $1^{\text {st }}$ & 1.302 & $1^{\text {st }}$ & 1.287 \\
\hline BRSCIRAD 302 & 2010 & 0.93 & $2^{\text {nd }}$ & 9247 & $1^{\text {st }}$ & 10280 & $4^{\text {th }}$ & 1.187 & $4^{\text {th }}$ & 1.177 \\
\hline BRS Pampeira & 2016 & 0.96 & $3^{\text {rd }}$ & 9216 & $5^{\text {th }}$ & 8625 & $2^{\text {nd }}$ & 1.209 & $2^{\text {nd }}$ & 1.193 \\
\hline BRSCIRAD AH703 CL & 2017 & 0.96 & $4^{\text {th }}$ & 9093 & $6^{\text {th }}$ & 8590 & $3^{\text {rd }}$ & 1.198 & $3^{\text {rd }}$ & 1.188 \\
\hline BR/IRGA 412 & 1986 & 0.91 & $5^{\text {th }}$ & 8783 & $2^{\text {nd }}$ & 9514 & $5^{\text {th }}$ & 1.144 & $5^{\text {th }}$ & 1.141 \\
\hline BRS 7 Taim & 1991 & 0.97 & $6^{\text {th }}$ & 8641 & $9^{\text {th }}$ & 8322 & $6^{\text {th }}$ & 1.123 & $6^{\text {th }}$ & 1.117 \\
\hline BRS Pelota & 2000 & 0.97 & $7^{\text {th }}$ & 8557 & $8^{\text {th }}$ & 8482 & $8^{\text {th }}$ & 1.108 & $8^{\text {th }}$ & 1.093 \\
\hline BRS Agrisul & 1995 & 0.90 & $8^{\text {th }}$ & 8533 & $4^{\text {th }}$ & 9253 & $7^{\text {th }}$ & 1.113 & $7^{\text {th }}$ & 1.108 \\
\hline BR/IRGA 410 & 1980 & 0.97 & $9^{\text {th }}$ & 8377 & $12^{\text {th }}$ & 8070 & $9^{\text {th }}$ & 1.080 & $10^{\text {th }}$ & 1.070 \\
\hline BRS Fronteira & 2005 & 0.97 & $10^{\text {th }}$ & 8280 & $11^{\text {th }}$ & 8122 & $11^{\text {th }}$ & 1.075 & $11^{\text {th }}$ & 1.066 \\
\hline BRS 358 & 2015 & 0.93 & $11^{\text {th }}$ & 8259 & $10^{\text {th }}$ & 8234 & $12^{\text {th }}$ & 1.074 & $9^{\text {th }}$ & 1.070 \\
\hline BRS Querência & 2005 & 0.97 & $12^{\text {th }}$ & 8239 & $13^{\text {th }}$ & 7930 & $10^{\text {th }}$ & 1.075 & $12^{\text {th }}$ & 1.060 \\
\hline BR/IRGA 409 & 1979 & 0.97 & $13^{\text {th }}$ & 8185 & $14^{\text {th }}$ & 7909 & $13^{\text {th }}$ & 1.066 & $13^{\text {th }}$ & 1.060 \\
\hline BRS Sinuelo CL & 2010 & 0.97 & $14^{\text {th }}$ & 8058 & $16^{\text {th }}$ & 7589 & $14^{\text {th }}$ & 1.056 & $14^{\text {th }}$ & 1.047 \\
\hline BR/IRGA 413 & 1986 & 0.91 & $15^{\text {th }}$ & 7963 & $7^{\text {th }}$ & 8563 & $15^{\text {th }}$ & 1.035 & $15^{\text {th }}$ & 1.026 \\
\hline BRS 6 Chuí & 1991 & 0.97 & $16^{\text {th }}$ & 7779 & $15^{\text {th }}$ & 7806 & $16^{\text {th }}$ & 1.012 & $16^{\text {th }}$ & 1.002 \\
\hline BRS AG & 2015 & 0.93 & $17^{\text {th }}$ & 7290 & $19^{\text {th }}$ & 6914 & $17^{\text {th }}$ & 0.935 & $17^{\text {th }}$ & 0.905 \\
\hline BR/IRGA 414 & 1987 & 0.90 & $18^{\text {th }}$ & 6765 & $17^{\text {th }}$ & 7273 & $18^{\text {th }}$ & 0.874 & $18^{\text {th }}$ & 0.872 \\
\hline IAS 12-9 (Formosa) & 1972 & 0.91 & $19^{\text {th }}$ & 6689 & $18^{\text {th }}$ & 7005 & $20^{\text {th }}$ & 0.864 & $20^{\text {th }}$ & 0.839 \\
\hline BRS Firmeza & 1999 & 0.96 & $20^{\text {th }}$ & 6672 & $20^{\text {th }}$ & 6538 & $19^{\text {th }}$ & 0.867 & $19^{\text {th }}$ & 0.845 \\
\hline BRS Bojuru & 1997 & 0.91 & $21^{\mathrm{st}}$ & 5958 & $21^{\mathrm{st}}$ & 6273 & $21^{\mathrm{st}}$ & 0.764 & $21^{\mathrm{st}}$ & 0.753 \\
\hline SCSBRS 113 - Tio Taka & 2004 & 0.88 & $22^{\text {nd }}$ & 5831 & $23^{\text {rd }}$ & 5826 & $23^{\text {rd }}$ & 0.733 & $23^{\text {rd }}$ & 0.710 \\
\hline BRS Atalanta & 1999 & 0.96 & $23^{\text {rd }}$ & 5679 & $24^{\text {th }}$ & 5766 & $22^{\text {nd }}$ & 0.748 & $22^{\text {nd }}$ & 0.721 \\
\hline BR/IRGA 411 & 1985 & 0.91 & $24^{\text {th }}$ & 5574 & $22^{\text {nd }}$ & 5856 & $24^{\text {th }}$ & 0.715 & $24^{\text {th }}$ & 0.701 \\
\hline BRS Ligeirinho & 1995 & 0.90 & $25^{\text {th }}$ & 5067 & $25^{\text {th }}$ & 5275 & $25^{\text {th }}$ & 0.649 & $25^{\text {th }}$ & 0.629 \\
\hline
\end{tabular}

${ }^{(1)} \mathrm{YL}$, year of cultivar release. ${ }^{(2)} \mathrm{R}^{\mathrm{o}}$, ranking of the cultivars, according to the parameters of the analyses. 
and an environmental index of $+2,344 \mathrm{~kg} \mathrm{ha}^{-1}$; and the least favorable was the Depressão Central region, with an average yield of $6,752 \mathrm{~kg} \mathrm{ha}^{-1}$, and an environmental index of $-1,293 \mathrm{~kg} \mathrm{ha}^{-1}$. Slightly different responses were reported in experiments performed in the regions Depressão Central, Fronteira Oeste, Planície Costeira Externa and Interna, and Zona Sul, showing average yields of 7,938, 9,774, 8,501, 8,314, and 9,759 $\mathrm{kg} \mathrm{ha}^{-1}$, respectively (Rosa et al., 2015). These contrasting results can be explained by the distinction in the group of evaluated cultivars in each study, which shows the importance of these GxE studies to define an agricultural zoning, with the purpose of recommending regionalized cultivars and selecting trial sites.

It is also important to verify the response as for the genotypic yield of cultivars in favorable and

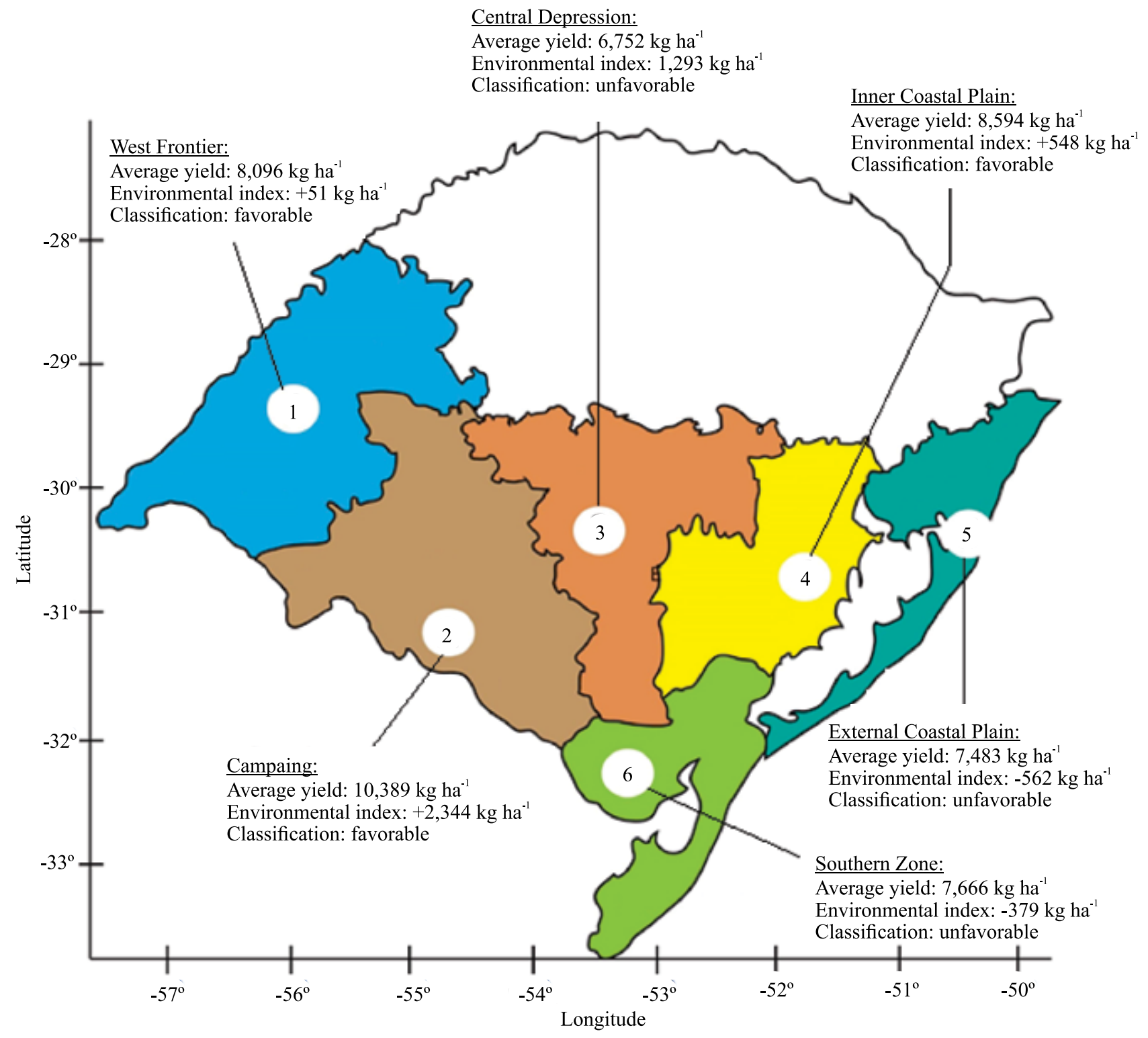

Figure 1. Average yield, environmental index, and classification of irrigated rice (Oryza sativa) cultivars conducted in 11 harvest seasons, in the six rice regions of the state of Rio Grande do Sul, Brazil. 
unfavorable environmental conditions (Table 4). In favorable environments, three highly responsive cultivars stood out, with yields higher than 10,000 kg ha' ${ }^{-1}$ 'BRS Pampa' (10,593 kg ha-1), 'BRS Pampeira' $\left(10,423 \mathrm{~kg} \mathrm{ha}^{-1}\right)$, and 'BRS Pelota' (10,105 kg ha-1). Besides these, several others showed satisfactory yield potentials under favorable cultivation conditions, with general genotypic means of $8,667 \mathrm{~kg} \mathrm{ha}^{-1}$. However, in cultivation environments considered unfavorable, the genotypic mean of the cultivars was much lower $\left(7,298 \mathrm{~kg} \mathrm{ha}^{-1}\right)$, and only 'BRS Pampa' displayed yield above $9,000 \mathrm{~kg} \mathrm{ha}^{-1}$. This small difference in genotypic yield $\left(\Delta \hat{\mathrm{G}}_{\mathrm{i}}\right)$, when different cultivated conditions were compared, shows the excellent yield capacity associated to a good stability of this cultivar regarding grain yield, which makes 'BRS Pampa' indicated for cultivation in all rice regions of the state.
Genotypic estimates of favorable agronomic attributes for rice improvement are displayed (Table 5). Among the cultivars released after the end of the 1970s, only 'BR/IRGA 411' and 'BRS AG' were taller than $100 \mathrm{~cm}$. It should be noted that 'BRS AG' was developed and released recently for ethanol production or animal feed (Magalhães Júnior et al., 2017b).

The discovery of the $s d-1$ gene, responsible for the semidwarf rice, allowed breeders to include this phenotype (associated with other agronomic traits of interest) into flood-irrigated rice cultivars leading to increased yield potential, especially 'BR/IRGA 409' and 'BR/IRGA 410' in Rio Grande do Sul (Streck et al., 2017). In this context, it is verified that a large share of the cultivars released by the Embrapa breeding program, after the two mentioned ones, have aimed at lower-stature genotypes.

Table 4. Classification of the cultivars $\left(\mathrm{R}^{\mathrm{o}}\right)$ according to the response of predicted genotypic values for grain yield $(\mathrm{kg}$ ha-1) and the yield difference of each cultivar, on average, in favorable and unfavorable environmental conditions $\left(\Delta \hat{\mathrm{G}}_{\mathrm{i}}\right)$ for 25 irrigated rice (Oryza sativa) cultivars in the state of Rio Grande do Sul, Brazil.

\begin{tabular}{|c|c|c|c|c|c|c|}
\hline Cultivar & $\mathrm{R}^{\mathrm{o}}$ & $\begin{array}{c}\text { Favorable } \\
\left(\mathrm{kg} \mathrm{ha}^{-1}\right)\end{array}$ & $\mathrm{R}^{\mathrm{o}}$ & $\begin{array}{c}\text { Unfavorable } \\
\left(\mathrm{kg} \mathrm{ha}^{-1}\right)\end{array}$ & $\mathrm{R}^{\mathrm{o}}$ & $\begin{array}{c}\Delta \hat{\mathrm{G}}_{\mathrm{i}} \\
\left(\mathrm{kg} \mathrm{ha}^{-1}\right)\end{array}$ \\
\hline BRS Pampa & $1^{\text {st }}$ & 10,593 & $1^{\mathrm{st}}$ & 9,436 & $15^{\text {th }}$ & 1,157 \\
\hline BRS Pampeira & $2^{\text {nd }}$ & 10,423 & $3^{\text {rd }}$ & 8,651 & $8^{\text {th }}$ & 1,772 \\
\hline BRS Pelota & $3^{\text {rd }}$ & 10,105 & $6^{\text {th }}$ & 8,185 & $4^{\text {th }}$ & 1,920 \\
\hline BR/IRGA 410 & $4^{\text {th }}$ & 9,980 & $9^{\text {th }}$ & 7,946 & $2^{\text {nd }}$ & 2,033 \\
\hline BRS 7 Taim & $5^{\text {th }}$ & 9,895 & $8^{\text {th }}$ & 8,109 & $7^{\text {th }}$ & 1,786 \\
\hline BRSCIRAD 302 & $6^{\text {th }}$ & 9,741 & $2^{o}$ & 8,971 & $23^{\text {rd }}$ & 771.0 \\
\hline BRS Querência & $7^{\text {th }}$ & 9,600 & $14^{\text {th }}$ & 7,776 & $5^{\text {th }}$ & 1,824 \\
\hline BRSCIRAD AH703 CL & $8^{\text {th }}$ & 9,595 & $4^{\text {th }}$ & 8,517 & $16^{\text {th }}$ & 1,078 \\
\hline BR/IRGA 412 & $9^{\text {th }}$ & 9,559 & $5^{\text {th }}$ & 8,488 & $17^{\text {th }}$ & 1,072 \\
\hline BRS Agrisul & $10^{\text {th }}$ & 9,528 & $7^{\text {th }}$ & 8,159 & $14^{\text {th }}$ & 1,369 \\
\hline BRS Fronteira & $11^{\text {th }}$ & 9,352 & $10^{\text {th }}$ & 7,873 & $11^{\text {th }}$ & 1,478 \\
\hline BR/IRGA 409 & $12^{\text {th }}$ & 9,272 & $13^{\text {th }}$ & 7,792 & $10^{\text {th }}$ & 1,480 \\
\hline BRS 6 Chuí & $13^{\text {th }}$ & 9,097 & $16^{\text {th }}$ & 7,378 & $9^{\text {th }}$ & 1,719 \\
\hline BRS 358 & $14^{\text {th }}$ & 8,757 & $11^{\text {th }}$ & 7,844 & $20^{\text {th }}$ & 913.0 \\
\hline BRS Sinuelo CL & $15^{\text {th }}$ & 8,546 & $12^{\text {th }}$ & 7,812 & $24^{\text {th }}$ & 734.0 \\
\hline BR/IRGA 413 & $16^{\text {th }}$ & 8,525 & $15^{\text {th }}$ & 7,728 & $21^{\mathrm{st}}$ & 797.0 \\
\hline BRS Firmeza & $17^{\text {th }}$ & 7,955 & $20^{\text {th }}$ & 6,136 & $6^{\text {th }}$ & 1,819 \\
\hline BR/IRGA 414 & $18^{\text {th }}$ & 7,824 & $19^{\text {th }}$ & 6,348 & $12^{\text {th }}$ & 1,476 \\
\hline BRS AG & $19^{\text {th }}$ & 7,730 & $17^{\text {th }}$ & 6,959 & $22^{\text {nd }}$ & 771.0 \\
\hline BRS Atalanta & $20^{\text {th }}$ & 7,587 & $23^{\text {rd }}$ & 5,204 & $1^{\mathrm{st}}$ & 2,383 \\
\hline IAS 12-9 (Formosa) & $21^{\mathrm{st}}$ & 7,073 & $18^{\text {th }}$ & 6,496 & $25^{\text {th }}$ & 577.0 \\
\hline SCSBRS 113 - Tio Taka & $22^{\text {nd }}$ & 6,999 & $24^{\text {th }}$ & 5,061 & $3^{\text {rd }}$ & 1,938 \\
\hline BRS Bojuru & $23^{\text {rd }}$ & 6,605 & $21^{\mathrm{st}}$ & 5,668 & $19^{\text {th }}$ & 937.0 \\
\hline BR/IRGA 411 & $24^{\text {th }}$ & 6,281 & $22^{\text {th }}$ & 5,260 & $18^{\text {th }}$ & 1,022 \\
\hline BRS Ligeirinho & $25^{\text {th }}$ & 6,044 & $25^{\text {th }}$ & 4,656 & $13^{\text {th }}$ & 1,388 \\
\hline Average & - & 8,667 & - & 7,298 & - & 1,368 \\
\hline
\end{tabular}


As for the trait days to flowering (DTF), most of the released cultivars were observed as displaying cycles ranging from early (between 80 and 90 DTF) to medium (between 91 and 100 DTF). However, 'BRS Ligeirinho' and 'BRS Atalanta' display super-early cycles $(<80 \mathrm{DTF})$, which puts them as alternatives to specific cultivation conditions. At the other extreme, 'SCSBRS 113 - Tio Taka', obtained by recurrent selection (Rangel et al., 2007), showed a very late cycle ( $>101$ days to flowering) for the cultivation conditions of Rio Grande do Sul. This cultivar was developed and released specially for the State of Santa Catarina. The long cycle until flowering can explain the lowyield potential showed by this cultivar in the state of Rio Grande do Sul (Table 3). Rio Grande do Sul has a higher probability of low temperatures (Steinmetz et al., 2003) and low luminosity (Klering et al., 2008) at late February and early March.
Grain quality is also a widely considered parameter for the flood-irrigated rice improvement, as it determines the market value of the cereal. In this sense, the majority of the cultivars recently released by the breeding program have a high index of whole grains after milling, which is the main trait referring to rice industrial quality (Table 5). It should be noted that 'BRS Pampa', 'BRS Pampeira' and 'BRSCIRAD 302' which were outstanding for grain yield, also showed high-grain quality with, respectively, 62.19, 60.28 and $60.91 \%$ whole grains after milling.

Therefore, it can be considered that a wide range of flood-irrigated rice cultivars, developed by the Embrapa breeding program, shows good agronomic attributes for different cultivation conditions in the state of Rio Grande do Sul.

Table 5. Estimates of predicted genotypic values $\left(\hat{\mathrm{G}}_{\mathrm{i}}\right)$ and selective accuracy $\left(\hat{\mathrm{r}}_{\mathrm{g} g}\right)$ for the traits number of days to flowering (DTF), plant height (PH), and percentage of whole grains after milling (WG) of 25 irrigated rice (Oryza sativa) cultivars, evaluated in 60 environments in the state of Rio Grande do Sul, Brazil.

\begin{tabular}{|c|c|c|c|c|c|c|c|}
\hline \multirow[t]{2}{*}{ Cultivar } & \multirow[t]{2}{*}{ Release } & \multicolumn{2}{|c|}{ DTF (days) } & \multicolumn{2}{|c|}{ Plant height $(\mathrm{cm})$} & \multicolumn{2}{|c|}{ WG $(\%)$} \\
\hline & & $\hat{\mathrm{G}}_{\mathrm{i}}$ & $\hat{\mathrm{r}}_{\hat{\mathrm{g} g}}$ & $\hat{\mathrm{G}}_{\mathrm{i}}$ & $\hat{\mathrm{r}}_{\hat{\mathrm{g} g}}$ & $\hat{\mathrm{G}}_{\mathrm{i}}$ & $\hat{\mathrm{r}}_{\hat{\mathrm{g} g}}$ \\
\hline BRS Ligeirinho & 1995 & 69 & 0.94 & 83.23 & 0.94 & 60.50 & 0.70 \\
\hline BRS Atalanta & 1999 & 72 & 0.97 & 91.54 & 0.97 & 58.99 & 0.88 \\
\hline BR/IRGA 414 & 1987 & 81 & 0.94 & 92.72 & 0.94 & 62.40 & 0.73 \\
\hline BRS 6Chuí & 1991 & 81 & 0.97 & 90.32 & 0.97 & 60.80 & 0.92 \\
\hline BRS Querência & 2005 & 81 & 0.98 & 96.01 & 0.98 & 59.05 & 0.94 \\
\hline BRS Firmeza & 1999 & 84 & 0.97 & 89.13 & 0.97 & 61.99 & 0.90 \\
\hline BRSCIRAD AH703 CL & 2017 & 84 & 0.97 & 93.02 & 0.97 & 62.85 & 0.88 \\
\hline BRS Pampa & 2011 & 85 & 0.97 & 95.33 & 0.97 & 62.19 & 0.92 \\
\hline BRS 358 & 2015 & 88 & 0.96 & 86.42 & 0.96 & 62.04 & 0.78 \\
\hline BRS Pelota & 2000 & 89 & 0.97 & 95.58 & 0.97 & 60.51 & 0.92 \\
\hline BR/IRGA 410 & 1980 & 91 & 0.98 & 96.81 & 0.98 & 61.66 & 0.94 \\
\hline BRS Sinuelo CL & 2010 & 91 & 0.97 & 86.51 & 0.97 & 61.45 & 0.92 \\
\hline BRSCIRAD 302 & 2010 & 91 & 0.96 & 98.31 & 0.96 & 60.91 & 0.82 \\
\hline BR/IRGA 411 & 1985 & 92 & 0.94 & 108.83 & 0.94 & 58.20 & 0.75 \\
\hline BRS AG & 2015 & 92 & 0.96 & 109.50 & 0.96 & 56.21 & 0.78 \\
\hline BR/IRGA 412 & 1986 & 92 & 0.94 & 91.51 & 0.94 & 60.89 & 0.75 \\
\hline IAS 12-9 (Formosa) & 1972 & 92 & 0.94 & 104.55 & 0.94 & 58.17 & 0.74 \\
\hline BRS 7 Taim & 1991 & 92 & 0.98 & 89.60 & 0.98 & 61.14 & 0.94 \\
\hline BRS Agrisul & 1995 & 93 & 0.94 & 94.03 & 0.94 & 56.91 & 0.75 \\
\hline BR/IRGA 413 & 1986 & 93 & 0.94 & 98.38 & 0.94 & 62.86 & 0.75 \\
\hline BRS Bojuru & 1997 & 93 & 0.94 & 92.98 & 0.94 & 59.49 & 0.75 \\
\hline BR/IRGA 409 & 1979 & 94 & 0.98 & 93.95 & 0.98 & 62.49 & 0.94 \\
\hline BRS Fronteira & 2005 & 94 & 0.97 & 95.08 & 0.97 & 63.32 & 0.93 \\
\hline BRS Pampeira & 2016 & 99 & 0.97 & 96.07 & 0.97 & 60.28 & 0.88 \\
\hline SCSBRS 113 - Tio Taka & 2004 & 114 & 0.94 & 86.05 & 0.94 & 61.16 & 0.70 \\
\hline
\end{tabular}




\section{Conclusions}

1. 'BRS Pampa', 'BRS Pampeira', and 'BRSCIRAD 302 ' rice (Oryza sativa) show, simultaneously, highgenotypic grain yield, adaptability, stability, good agronomic attributes and good whole-grain yield after milling.

2. 'BRSCIRAD 302' and 'BRS Pampa' show high-yield stability, which makes them suitable for cultivation in all rice regions of Rio Grande do Sul; and 'BRS Pampeira' is a highly responsive cultivar to environmental improvements and is, therefore, indicated for high-technology conditions.

\section{Acknowledgments}

To Conselho Nacional de Desenvolvimento Científico e Tecnológico (CNPq) and to Coordenação de Aperfeiçoamento de Pessoal de Nível Superior (Capes), for grants and fellowships; and to Embrapa Clima Temperado, for technical, scientific, and infrastructure support.

\section{References}

BALESTRE, M.; SANTOS, V.B. dos; SOARES, A.A.; REIS, M.S. Stability and adaptability of upland rice genotypes. Crop Breeding and Applied Biotechnology, v.10, p.357-363, 2010. DOI: $10.1590 / \mathrm{S} 1984-70332010000400011$.

BASTOS, I.T.; BARBOSA, M.H.P.; RESENDE, M.D.V. de; PETERNELLI, L.A.; SILVEIRA, L.C.I. da; DONDA, L.R.; FORTUNATO, A.A.; COSTA, P.M. de A.; FIGUEIREDO, I.C.R. de. Avaliação da interação genótipo $\mathrm{x}$ ambiente em cana-deaçúcar via modelos mistos. Pesquisa Agropecuária Tropical, v. 37, p.195-203, 2007.

BORGES, V.; SOARES, A.A.; REIS, M.S.; RESENDE, M.D.V.; CORNÉLIO, V.M.O.; LEITE, N.A.; VIEIRA, A.R. Desempenho genotípico de linhagens de arroz de terras altas utilizando metodologia de modelos mistos. Bragantia, v.69, p.833-841, 2010. DOI: $10.1590 / \mathrm{S} 0006-87052010000400008$.

CAMERON, D.K.; WANG, Y.J.; MOLDENHAUER, K.A. Comparison of physical and chemical properties of mediumgrain rice cultivars grown in California and Arkansas. Journal of Food Science, v.73, p.c.72-78, 2008. DOI: 10.1111/j.17503841.2007.00631.x.

COLOMBARI FILHO, J.M.; RESENDE, M.D.V. de; MORAIS, O.P. de; CASTRO, A.P. de; GUIMARÃES, É.P.; PEREIRA, J.A.; UTUMI, M.M.; BRESEGHELLO, F. Upland rice breeding in Brazil: a simultaneous genotypic evaluation of stability, adaptability and grain yield. Euphytica, v.192, p.117-129, 2013. DOI: 10.1007/s10681-013-0922-2.
FARIA, S.V.; LUZ, L.S.; RODRIGUES, M.C.; CARNEIRO, J.E. de S.; CARNEIRO, P.C.S.; DELIMA, R.O. Adaptability and stability in commercial maize hybrids in the southeast of the State of Minas Gerais, Brazil. Revista Ciência Agronômica, v.48, p.347-357, 2017. DOI: 10.5935/1806-6690.20170040.

HAKATA, M.; KURODA, M.; MIYASHITA, T.; YAMAGUCHI, T.; KOJIMA, M.; SAKAKIBARA, H.; MITSUI T.; YAMAKAWA, $H$. Suppression of $\alpha$-amylase genes improves quality of rice grain ripened under high temperature. Plant Biotechnology Journal, v.10, p.1110-1117, 2012. DOI: 10.1111/j.1467-7652.2012.00741.x.

HAO, W.; LIN, H.-X. Toward understanding genetic mechanisms of complex traits in rice. Journal of Genetics and Genomics, v.37, p.653-666, 2010. DOI: 10.1016/S1673-8527(09)60084-9.

KLERING, E.V.; FONTANA, D.C., BERLATO, M.A.; CARGNELUTTI FILHO, A. Modelagem agrometeorológica do rendimento de arroz irrigado no Rio Grande do Sul. Pesquisa Agropecuária Brasileira, v.43, p.549-558, 2008. DOI: 10.1590/ S0100-204X2008000500001.

LI, Y.; FAN, C.; XING, Y.; YUN, P.; LUO, L.; YAN, B.; PENG, B.; XIE, W.; WANG, G.; LI, X.; XIAO, J.; XU, C.; HE, Y. Chalk5 encodes a vacuolar $\mathrm{H}^{+}$-translocating pyrophosphatase influencing grain chalkiness in rice. Nature Genetics, v.46, p.398-404, 2014. DOI: 10.1038/ng.2923.

LYMAN, N.B.; JAGADISH, K.S.V.; NALLEY, L.L.; DIXON, B.L.; SIEBENMORGEN, T. Neglecting rice milling yield and quality underestimates economic losses from high-temperature stress. PLoS ONE, v.8, e72157, 2013. DOI: 10.1371/journal. pone. 0072157 .

MAGALHÃES JÚNIOR, A.M. de; MORAIS, O.P. de; FAGUNDES, P.R.R.; COLOMBARIFILHO, J.M.;FRANCO,D.F.; CORDEIRO, A.C.C.; PEREIRA, J.A.; RANGEL, P.H.N.; MOURA NETO, F.P.; STRECK, E.A.; AGUIAR, G.A.; FACCHINELLO, P.H.K. BRS Pampeira: new irrigated rice cultivar with high yield potential. Crop Breeding and Applied Biotechnology, v.17, p.78-83, 2017a. DOI: 10.1590/1984-70332017v17n1c13.

MAGALHÃES JÚNIOR, A.M.; FAGUNDES, P.R.R.; FRANCO, D.F.; MORAIS, O.P. de; SIQUEIRA, F.G.; STRECK, E.A.; AGUIAR, G.A.; FACCHINELLO, P.H.K. BRS AG: first cultivar of irrigated rice used for alcohol production or animal feed. Crop Breeding and Applied Biotechnology, v.17, p.72-77, 2017b. DOI: 10.1590/1984-70332017v17n1c12.

MENDES, F.F.; GUIMARÃES, L.J.M.; SOUZA, J.C.; GUIMARÃES, P.E.O.; PACHECO, C.A.P.; MACHADO, J.R. de A.; MEIRELLES, W.F.; SILVA, A.R. da; PARENTONI, S.N. Adaptability and stability of maize varieties using mixed model methodology. Crop Breeding and Applied Biotechnology, v.12, p.111-117, 2012. DOI: 10.1590/S1984-70332012000200003.

RANGEL, P.H.N.; BRONDANI, C.; MORAIS, O.P. de; SCHIOCCHET, M.A.; BORBA, T.C. de O.; RANGEL, P.N.; BRONDANI, R.P.V.; YOKOYAMA, S.; BACHA, R.E.; ISHY, T. Establishment of the irrigated rice cultivar SCSBRS Tio Taka by recurrent selection. Crop Breeding and Applied Biotechnology, v.7, p.103-110, 2007. DOI: 10.12702/1984-7033.v07n01a17. 
RESENDE, M.D.V. de. Software Selegen-REML/BLUP: a useful tool for plant breeding. Crop Breeding and Applied Biotechnology, v.16, p.330-339, 2016. DOI: 10.1590/198470332016v16n4a49.

RESENDE, M.D.V. de; DUARTE, J.B. Precisão e controle de qualidade em experimentos de avaliação de cultivares. Pesquisa Agropecuária Tropical, v.37, p.182-194, 2007.

RESENDE, M.D.V. Matemática e estatística na análise de experimentos e no melhoramento genético. Colombo: Embrapa Florestas, 2007. 561p.

ROSA, H.T.; WALTER, L.C.; STRECK, N.A.; DE CARLI, C.; RIBAS, G.G.; MARCHESAN, E. Simulação do crescimento e produtividade de arroz no Rio Grande do Sul pelo modelo SimulArroz. Revista Brasileira de Engenharia Agrícola e Ambiental, v.19, p.1159-1165, 2015. DOI: 10.1590/1807-1929/ agriambi.v19n12p1159-1165.

SILVA, G.A.P.; CHIORATO, A.F.; GONÇALVES, J.G.R.; PERINA, E.F.; CARBONELL, S.A.M. Análise da adaptabilidade e estabilidade de produção em ensaios regionais de feijoeiro para o Estado de São Paulo. Revista Ceres, v.60, p.59-65, 2013. DOI: 10.1590/S0034-737X2013000100009.

SILVA, G.O. da; CARVALHO, A.D.F. de; VIEIRA, J.V.; BENIN, G. Verificação da adaptabilidade e estabilidade de populações de cenoura pelos métodos AMMI, GGE biplot e REML/
BLUP. Bragantia, v.70, p.494-501, 2011. DOI: 10.1590/S000687052011005000003.

STEINMETZ, S.; ASSIS, F.N. de; BURIOL, G.A.; ESTEFANEL, V.; AMARAL, A.G.; FERREIRA, J.S.A. Mapeamento das probabilidades de ocorrência de temperaturas mínimas do ar, durante o período reprodutivo do arroz irrigado, no Estado do Rio Grande do Sul. Revista Brasileira de Agrometeorologia, v.11, p.169-179, 2003.

STRECK, E.A.; AGUIAR, G.A.; MAGALHÃES JÚNIOR, A.M. de; FACCHINELLO, P.H.K.; OLIVEIRA, A.C. de. Variabilidade fenotípica de genótipos de arroz irrigado via análise multivariada. Revista Ciência Agronômica, v.48, p.101-109, 2017. DOI: 10.5935/1806-6690.20170011.

TORRES, F.E.; TEODORO, P.E.; SAGRILO, E.; CECCON, G.; CORREA, A.M. Interação genótipo x ambiente em genótipos de feijão-caupi semiprostrado via modelos mistos. Bragantia, v.74, p.255-260, 2015. DOI: 10.1590/1678-4499.0099.

XU, Q.; CHEN, W.; XU, Z. Relationship between grain yield and quality in rice germplasms grown across different growing areas. Breeding Science, v.65, p.226-232, 2015. DOI: 10.1270/ jsbbs.65.226.

YOUNG, J.; VIRMANI, S.S. Heterosis in rice over environments. Euphytica, v.51, p.87-93, 1990. DOI: 10.1007/BF00022896.

Received on March 22, 2017 and accepted on December 19, 2017 